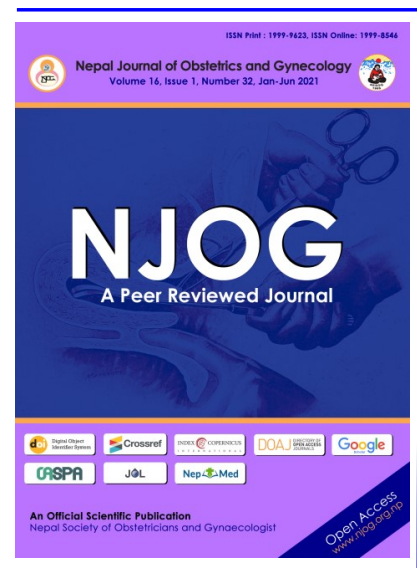

CORRESPONDENCE

Dr Alish Shrestha

Paropakar Maternity and Women's Hospital, Thapathali, Kathmandu, Nepal

Email:

alishsth2011@gmail.com; Phone: +977-9849852085

Received: April 15, 2021

Accepted: May 1, 2021

\section{Citation:}

Shrestha A, Baral G, Shakya B. Robson Ten Group Classification System and fetal distress as the indication for cesarean section. Nep J Obstet Gynecol. 2021;16(32):20-30. DOI: https://doi.org/10.3126/ njog.v16i1.37510

\title{
Robson Ten Group Classification System and fetal distress as the indication for cesarean section
}

\author{
Alish Shrestha, Gehanath Baral, Beemba Shakya \\ Paropakar Maternity and Women's Hospital, Thapathali, Kathmandu
}

ABSTRACT

Aim: To determine the association of Robson ten group classification system (RTGCS) and the fetal distress as an indication of CS among women delivering in Paropakar Maternity and Women's Hospital.

Methods: This was an observational cross-sectional study over a period of 6 months. 410 study sample population undergoing CS were stratified according to RTGCS out of total of 11575 women's delivering in PMWH and were analysed for indication of CS, fetal distress, maternal and fetal complications and their distribution according to RTGCS.

Results: Overall CS rate was $35.08 \%$. Largest group size was of group 1 with 4131 patients $(35.69 \%)$ followed by group 3 with 2980 patients $(25.75 \%)$. Highest contribution to CS rate was from group 5 (1070 patients, group CS rate 99.17\% and contribution to overall CS rate 26.35\%). Group 1 and 2 had low group CS rate in comparison to other groups but it was still higher than the Robson guidelines and MCS reference population as per WHO implementation guidelines. On analysis of sample study population CS rate due to fetal distress was $28.54 \%$ and previous CS was $25.85 \%$.

Conclusions: High proportion of women gave birth via CS among which high contribution was by low risk groups. The major indication of CS in low risk groups was fetal distress and there was significant rise of fetal distress after admission. Hence RTGCS neither could predict the indication of CS nor could correctly identify the actual high risk group. Hence incorporation of more objective indication of CS like fetal distress or high risk diagnosis which gives rise to fetal distress, in RTGCS criteria is recommended.

Keywords: cesarean section, fetal distress, indication, Robson classification

\section{INTRODUCTION}

There is rise in cesarean section (CS) rates in the past few decades, not only in developed countries but also in developing countries. The World Health Organization (WHO) states that CS rates should be between $10 \%$ and $15 \%{ }^{1}$ This rise in CS rate is due to the rise in number of women with previous $\mathrm{CS}$, increased use of electronic fetal monitoring which in turn identifies more cases as fetal distress. Robson Ten Group Classification System (RTGCS) is used to analyze the CS and to classify them to various groups and identifies the group with high (CS) percentage and is appropriate for long term tracking and international compar- ison of this increase in cesarean section trend. ${ }^{1,2}$

Hence, this study was focused to find out the frequency and indications of CS and analyze them to know the significant contributors to rise in cesarean section rates using RTGCS, and to analyze whether or not RTGCS can accurately predict the CS burden.

\section{METHODS}

It was a cross-sectional observational study conducted at Paropakar Maternity and Women's Hospital (PMWH) during $15^{\text {th }}$ June to $14^{\text {th }}$ December, 2020. Total women delivering during this time 
were classified according to RTGCS and Robson Classification report table was prepared and compared with Robson guideline and WHO MCS population. $^{3}$

Real time unpublished hospital data prior to study were used to calculate the sample size ${ }^{4,5}$ such as $29 \%$ CS rate, 650 per month and 204 fetal distress per month.

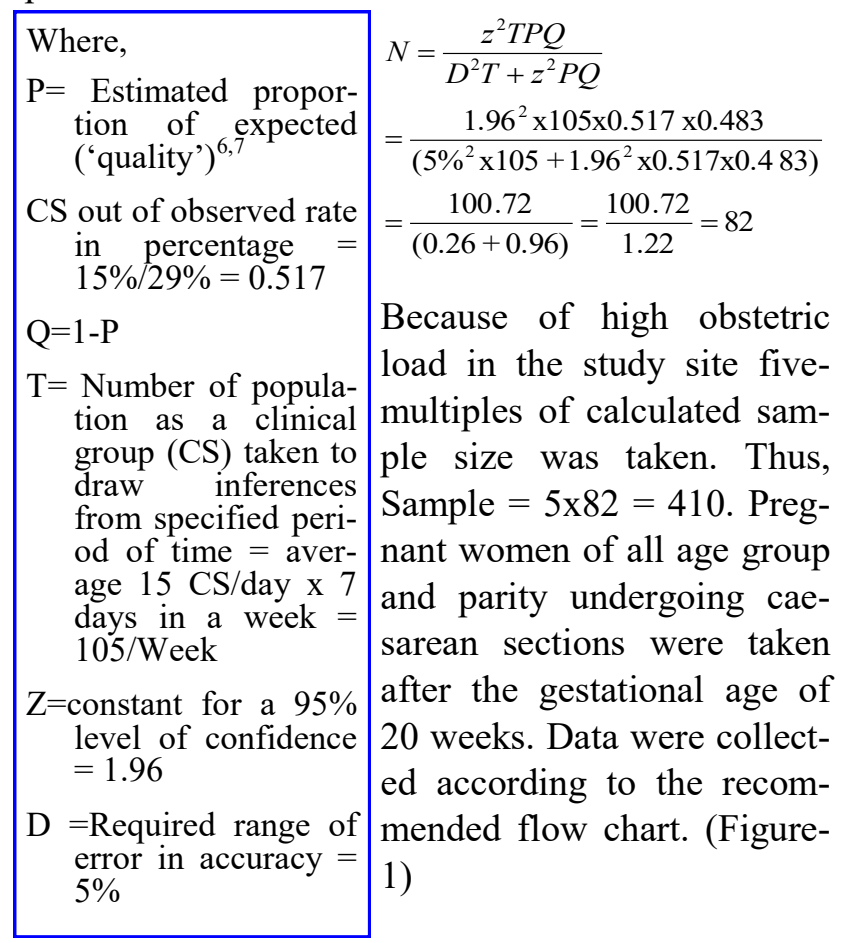

Obtained Data was entered using Microsoft Excel version 2010 and was analysed using IBM SPSS version 16. Chi square test was used to determine any association between variables with significance level at $5 \%(p<0.05$ considered to be statistically significant).

Data were assessed according to the RTGCS report table (Table-1). ${ }^{3}$

Table-1: Robson classification report table

Assessing type of population using the Robson Classification Report Table ${ }^{3}$

\begin{tabular}{|c|c|c|c|c|c|c|}
\hline 1 & 2 & 3 & 4 & 5 & 6 & 7 \\
\hline $\begin{array}{c}\text { Gro } \\
\text { up }\end{array}$ & $\begin{array}{l}\text { Num- } \\
\text { ber of } \\
\text { CS in } \\
\text { group }\end{array}$ & $\begin{array}{l}\text { Num- } \\
\text { ber of } \\
\text { wom- } \\
\text { en in } \\
\text { group }\end{array}$ & $\begin{array}{c}\text { Group } \\
\text { Size }^{1 *} \\
(\%)\end{array}$ & $\begin{array}{c}\text { Group } \\
\text { CS } \\
\text { rate }^{2^{*}} \\
(\%)\end{array}$ & $\begin{array}{l}\text { Absolute } \\
\text { group con- } \\
\text { tribution to } \\
\text { CS rate }{ }^{3 *} \\
(\%)\end{array}$ & $\begin{array}{l}\text { Relative } \\
\text { contribu- } \\
\text { tion of } \\
\text { group to } \\
\text { overall CS }^{\text {rate }^{*}(\%)}\end{array}$ \\
\hline
\end{tabular}

${ }^{1 *}$ Column $4=$ Group size $(\%)=n$ of women in the group / total $\mathrm{N}$ women delivered in the hospital $\mathrm{x} 100$ ${ }^{2 *}$ Column $5=$ Group CS rate $(\%)=\mathrm{n}$ of CS in the group $/$ total $\mathrm{N}$ of women in the group $\mathrm{x} 100$

${ }^{3 *}$ Column $6=$ Absolute contribution $(\%)=\mathrm{n}$ of CS in the group / total $\mathrm{N}$ of women delivered in the hospital $\mathrm{x}$ 100

${ }^{4 *}$ Column $7=$ Relative contribution $(\%)=\mathrm{n}$ of CS in the

\section{START HERE}

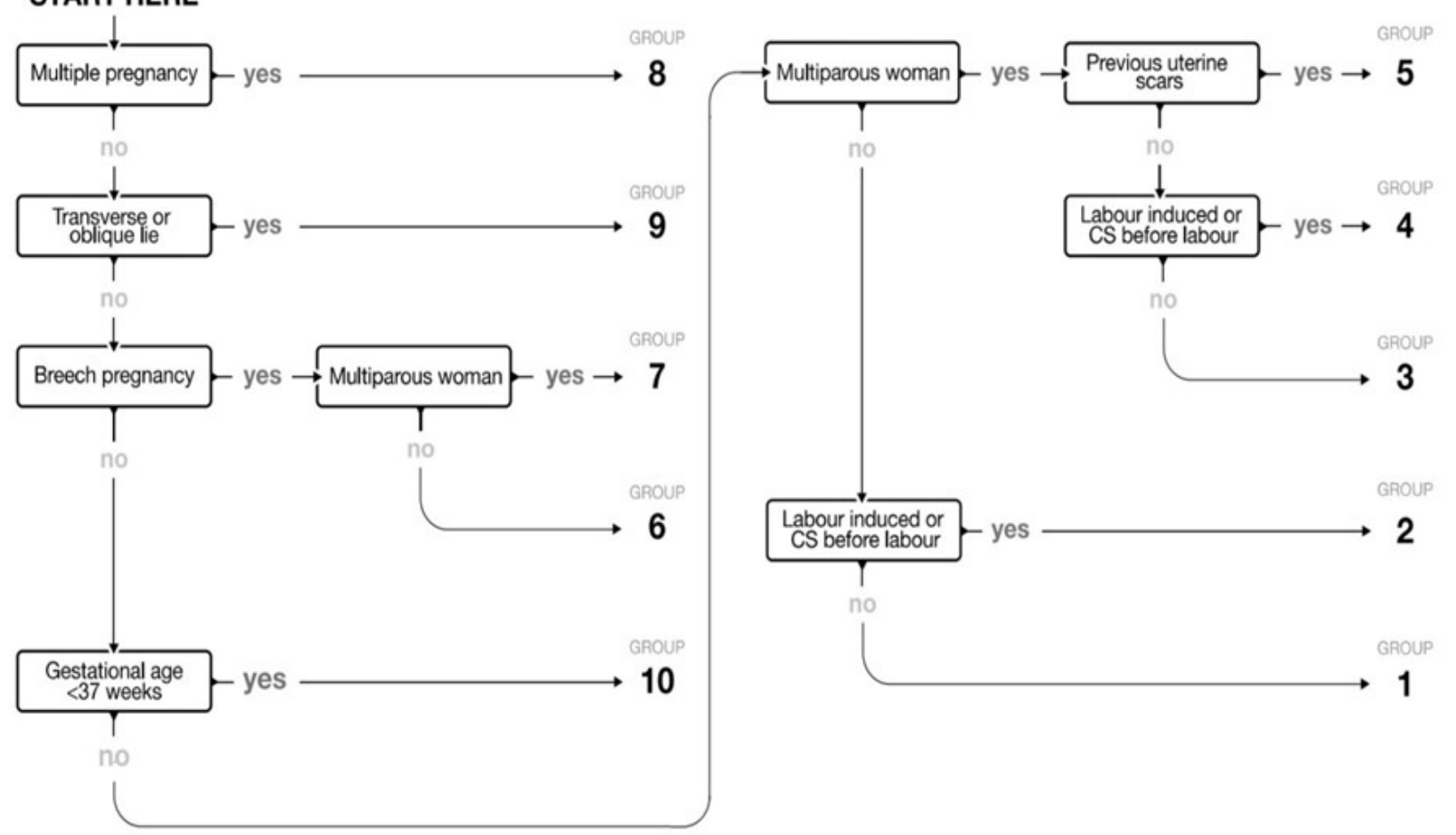

Figure-1: Data collection flow chart 


\section{RESULTS}

During the study period of 6 months, 11575 deliveries occurred in this hospital out of which 4061 patients (35.08\%) underwent CS and 7514 (64.91\%) patients delivered vaginally.

Largest population belonged to group 1with 4131 patients (35.69\%) followed by group 3 with 2980 patients $(25.75 \%)$. Highest contribution to CS rate was from group 5 (1070 patients, group CS rate $99.17 \%$, and contribution to overall CS rate $26.35 \%$ ). [Table-2]

Table-2: Robson Classification Report Table prepared from total population

\begin{tabular}{ccccccc}
\hline $\begin{array}{c}\text { RTGC } \\
\text { S }\end{array}$ & $\begin{array}{c}\text { Total population } \\
\text { of women un- } \\
\text { dergone CS }\end{array}$ & $\begin{array}{c}\text { Total popu- } \\
\text { lation of } \\
\text { women de- } \\
\text { livered }\end{array}$ & $\begin{array}{c}\text { Group } \\
\text { size\% }\end{array}$ & $\begin{array}{c}\text { Group } \\
\text { CS } \\
\text { rate\% } \%\end{array}$ & $\begin{array}{c}\text { Absolute } \\
\text { group contri- } \\
\text { bution to CS } \\
\text { rate\% } \%\end{array}$ & $\begin{array}{c}\text { Relative contribu- } \\
\text { tion of group to } \\
\text { overall CS rate \% }\end{array}$ \\
\hline 1 & 1002 & 4131 & 35.69 & 24.26 & 8.66 & 24.67 \\
$2 \mathrm{a}$ & 466 & 1290 & 11.14 & 36.12 & 4.03 & 11.48 \\
$2 \mathrm{~b}$ & 480 & 480 & 4.15 & 100.00 & 4.15 & 11.82 \\
3 & 300 & 2980 & 25.75 & 10.07 & 2.59 & 7.39 \\
$4 \mathrm{a}$ & 72 & 650 & 5.62 & 11.08 & 0.62 & 1.77 \\
$4 \mathrm{~b}$ & 180 & 180 & 1.56 & 100.00 & 1.56 & 4.43 \\
5 & 1070 & 1079 & 9.32 & 99.17 & 9.24 & 26.35 \\
6 & 134 & 136 & 1.17 & 98.53 & 1.16 & 3.30 \\
7 & 110 & 135 & 1.17 & 81.48 & 0.95 & 2.71 \\
8 & 50 & 53 & 0.46 & 94.34 & 0.43 & 1.23 \\
9 & 10 & 10 & 0.09 & 100.00 & 0.09 & 0.25 \\
10 & 187 & 451 & 3.90 & 41.46 & 1.62 & 4.60 \\
\hline Total & 4061 & 11575 & 100.00 & & & 100.00 \\
\hline \multicolumn{7}{c}{}
\end{tabular}

On evaluation of 410 sample patients enrolled in study; the mean age of the patients included in study was 26.66years \pm SD 4.9years, and had other parameters have been presented. [Table -3]

Table-3: Distribution of cases by obstetric parameters

\begin{tabular}{clcc}
\hline \multicolumn{2}{c}{ Parameters } & $\mathrm{N}$ & $\%$ \\
\hline \multirow{2}{*}{ Age } & $15-24$ years & 150 & $36.59 \%$ \\
Group & 25-34years & 230 & $56.10 \%$ \\
& $\geq 35$ years & 30 & $7.31 \%$ \\
\hline \multirow{3}{*}{ Weeks of } & 32 - $-<37$ weeks & 39 & $1.22 \%$ \\
Gestation & $37-<42$ weeks & 362 & $88.29 \%$ \\
& $\geq 42$ weeks & 4 & $0.98 \%$ \\
\hline \multirow{2}{*}{ Anc Vis- } & $<4$ & 191 & $46.58 \%$ \\
its & $\geq 4$ & 183 & $44.64 \%$ \\
& Unbooked & 36 & $8.78 \%$ \\
\hline \multirow{5}{*}{ Gravidity } & Primigravida & 179 & $43.66 \%$ \\
& G2 & 155 & $37.80 \%$ \\
& G3 & 51 & $12.44 \%$ \\
& G4 & 16 & $3.90 \%$ \\
& $\geq$ G5 & 9 & $2.2 \%$ \\
\hline \multirow{5}{*}{ Parity } & P0 & 211 & $51.46 \%$ \\
& P1 & 160 & $39.03 \%$ \\
& P2 & 33 & $8.06 \%$ \\
& P3 & 5 & $1.21 \%$ \\
& $\geq$ P4 & 1 & $0.24 \%$ \\
\hline
\end{tabular}

\begin{tabular}{clcc}
\hline \multicolumn{2}{c}{ Parameters } & $\mathrm{N}$ & $\%$ \\
\hline \multirow{2}{*}{ Abor- } & $\mathrm{A} 1$ & 60 & $77.93 \%$ \\
tion & $\mathrm{A} 2$ & 11 & $14.27 \%$ \\
& $\geq \mathrm{A} 3$ & 6 & $7.80 \%$ \\
\hline Fetus & Single & 406 & $99.02 \%$ \\
order & Multiple & 4 & $0.98 \%$ \\
\hline \multirow{3}{*}{ Lie Of } & Longitudinal & 403 & $98.29 \%$ \\
Fetus & Oblique & 1 & $0.24 \%$ \\
& Transverse & 4 & $0.98 \%$ \\
& Unstable & 2 & $0.49 \%$ \\
\hline \multirow{3}{*}{ Presen- } & Cephalic & 377 & $91.95 \%$ \\
tation & Breech & 29 & $7.07 \%$ \\
& Compound & 2 & $0.49 \%$ \\
& Cord & 2 & $0.49 \%$ \\
\hline \multirow{2}{*}{ Type Of } & Spontaneous & 192 & $46.83 \%$ \\
Labour & Induced & 61 & $14.88 \%$ \\
& Not In Labor & 157 & $38.29 \%$ \\
\hline \multirow{2}{*}{ Past Cs } & Yes & 128 & $31.22 \%$ \\
& No & 282 & $68.78 \%$ \\
\hline Past & 1 & 123 & $96.10 \%$ \\
CS\# & $\geq 2$ & 5 & $3.90 \%$ \\
\hline
\end{tabular}


On classifying according to RTGCS; 95 (23.17\%), 82 (20\%), 31 (7.56\%), $20 \quad(4.88 \%), \quad 113 \quad(27.56 \%), \quad 17$ (4.14\%), 12 (2.93\%), 4 (0.98\%), 4 $(0.98 \%)$ and 32 patients $(7.80 \%)$ belonged to the group $1,2,3,4,5,6,7$, 8,9 and 10 respectively.

Group 1 and 2 (nulliparous, term, single, cephalic, spontaneous or induced labor) which are low risk group had highest contribution to $\mathrm{CS}$ rate i.e. 177 patients $(43.17 \%)$ which is followed by group 5 i.e. 113 patients $(27.56 \%)$. One hundred and four patients (25.36\%) had previous CS as indication at admission, 75 patients $(18.29 \%)$ were in LPOL during admission, 48 patients $(11.70 \%)$ were postdated pregnancies admitted for induc-

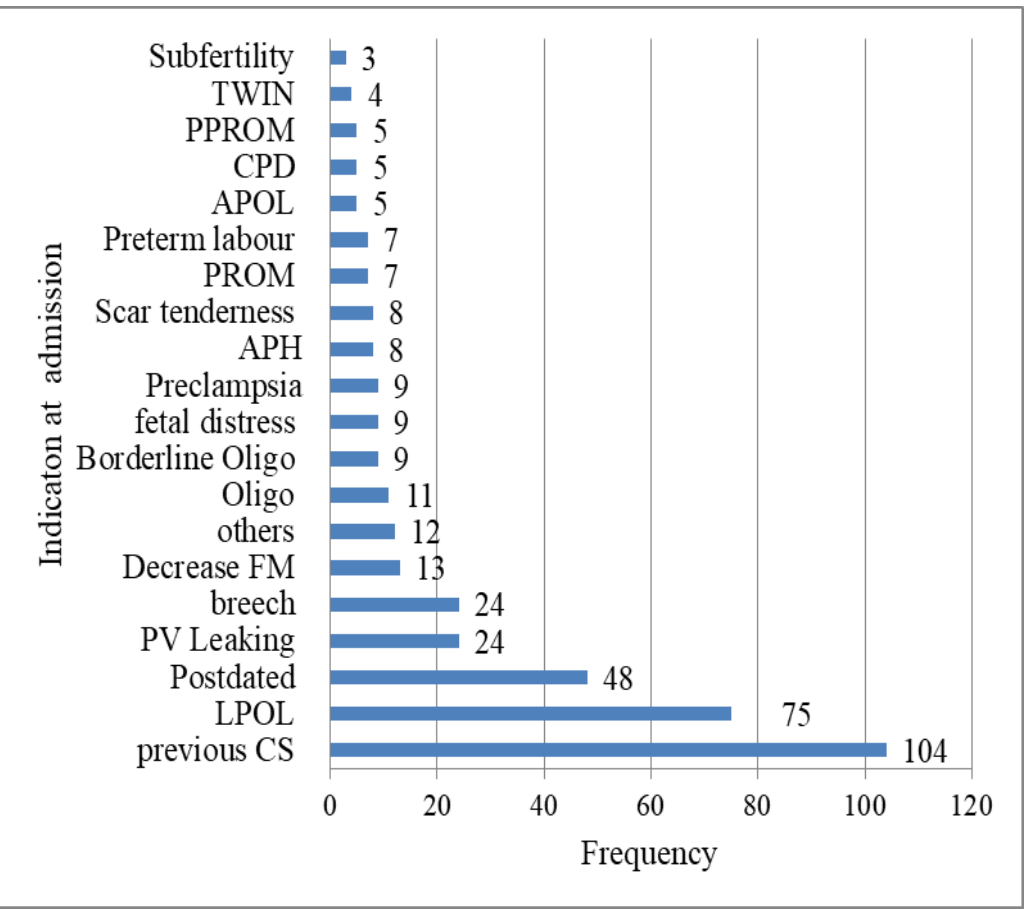

Figure-2: Distribution of patients according to indication at admission

One hundred and seventeen $(28.54 \%)$ had fetal distress as indication of CS followed by previous CS $(106 ; 25.85 \%)$, CPD $(36 ; 8.78 \%)$ and oligohydraminos $(30 ; 7.31 \%)$. [Figure-3]

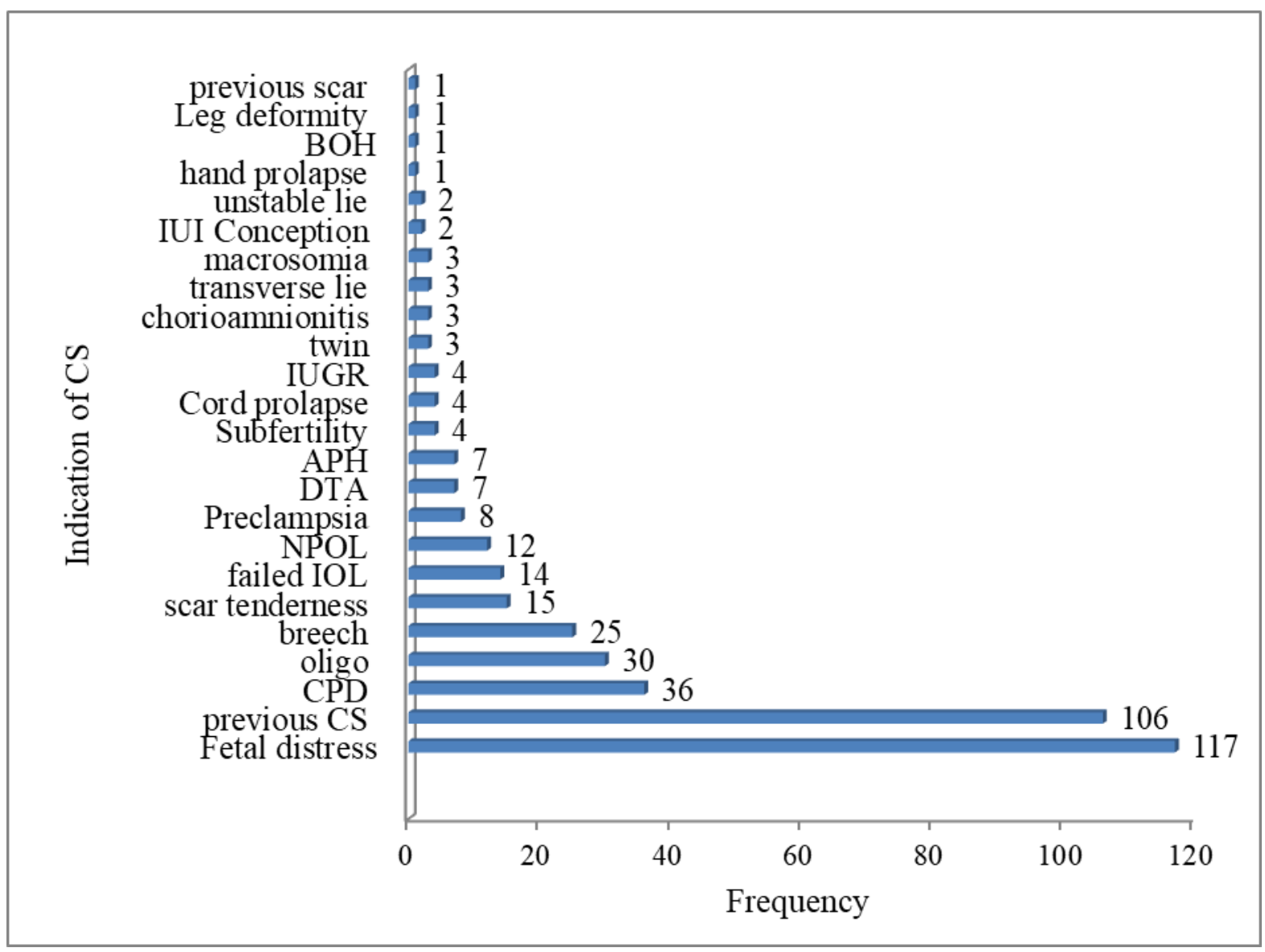

Figure-3: Distribution of patients according to indication of CS 
Out of 410 patients, 9 patients had fetal distress at admission diagnosis, 6 patients $(66.66 \%)$ from group 1 and 2 patients (22.22\%) from group 2. One hundred and seventeen patient had fetal distress as primary indication of CS of which 44 patients (37.61\%) belonged to group 1, 26 patients $(22.22 \%)$ belonged to group $2 \mathrm{a}$ and 22 patients $(18.80 \%)$ belonged to group 3 .

Low risk group (RTGCS 1,2a, 2b) were found to have statistically significant rise in rate of fetal distress after admission $(p<0.005)$. Also these groups had statistically significant relationship with fetal distress as indication for CS when compared to other group $(\mathrm{p}<0.005)$. [Table-4]

Table-4: Comparison of low risk (Group 1,2a, 2b) and non-low risk group for fetal distress as indication of CS

\begin{tabular}{|c|c|c|c|c|}
\hline & \multicolumn{2}{|c|}{$\begin{array}{l}\text { etal distress evolved after } \\
\text { admission }\end{array}$} & \multirow{2}{*}{\multicolumn{2}{|c|}{ Total p-value }} \\
\hline & yes & no & & \\
\hline Low risk & 71 & 106 & 177 & \\
\hline Non- Low risk & 37 & 196 & 233 & $<0.005$ \\
\hline \multirow[t]{2}{*}{ Total } & 108 & 302 & 410 & \\
\hline & dis dist & rimary in- & Total & p-value \\
\hline Low risk & $\frac{\text { yes }}{77}$ & $\frac{1 \text { NO }}{100}$ & 177 & \\
\hline $\begin{array}{l}\text { Non- Low } \\
\text { risk }\end{array}$ & 40 & 193 & 233 & $<0.005$ \\
\hline Total & 117 & 293 & 410 & \\
\hline
\end{tabular}

Out of 410 patients, 79 patients $(19.27 \%)$ had maternal complications. Most common complication being PPH with 53 patients (12.93\%), followed by GHTN with 23 patients $(5.61 \%)$ and blood transfusion with 21 patients $(5.12 \%)$. Nineteen patients (45.24\%) from group 2a, 12 patients (12.63\%) from group 1 and 11 patients $(9.73 \%)$ from group 5 had maternal complications. [Figure-4]

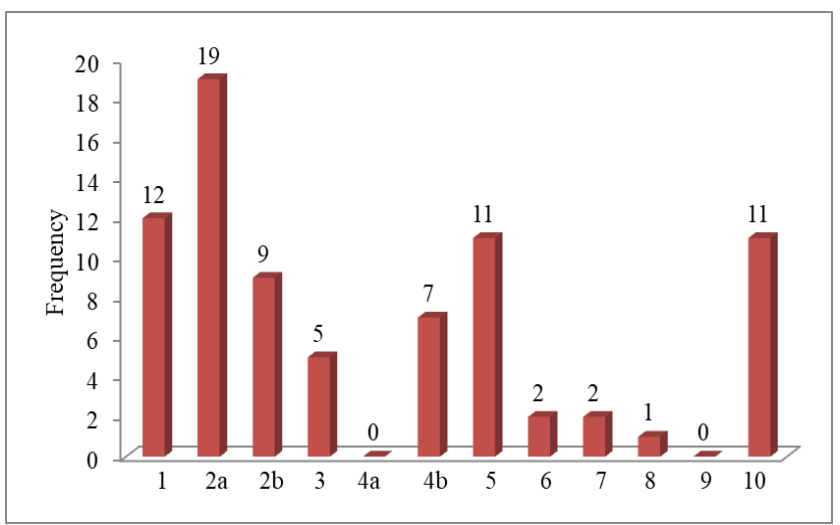

Figure-4: Distribution of patients according to maternal complication along RTGCS

\section{DISCUSSION}

Cesarean section rate was $35.08 \%$ similar rates (30\%-40.1\%) of CS were shown by four other studies. ${ }^{8-11}$.Largest group size was group 1 which had second highest contribution to overall CS result; similar results were obtained in eleven more studies. ${ }^{9-19}$ Group 5 had highest contribution to CS rate, similar results were shown by thirteen more studies. ${ }^{8,10,12-22}$

Group 6, 7, 8, 9 and 10 had relatively smaller group sizes $(1.17 \%, 1.17 \%, 0.46 \%, 0.09 \%$ and $3.90 \%$ respectively); and smaller contribution overall CS rates $(3.30 \%, 2.71 \%, 1.23 \%, 0.25 \%$ and $4.60 \%$ respectively) but had higher group CS rates $(98.53 \%, 81.48 \%, 94.34 \%, 100.00 \%$ and $41.46 \%$ respectively) similar findings were seen in eight more studies. ${ }^{9,13-17,20,22}$ The findings and their interpretation related to the data quality, the type of population and the CS rates can be summarized. [Table-5]

Table-5a: Assessment of quality of data using the Robson Classification Report Table of obtained from our study.

\begin{tabular}{|c|c|c|c|c|}
\hline Steps & $\begin{array}{l}\text { Interpre- } \\
\text { tation by } \\
\text { Robson }^{3}\end{array}$ & $\begin{array}{l}\text { MCS } \\
\text { popu- } \\
\text { lation }^{3}\end{array}$ & $\begin{array}{l}\text { This } \\
\text { study }\end{array}$ & $\begin{array}{l}\text { Further } \\
\text { Interpreta- } \\
\text { tion }^{3}\end{array}$ \\
\hline $\begin{array}{l}\text { 1. the } \\
\text { total no. } \\
\text { of CS } \\
\text { and of } \\
\text { women } \\
\text { deliv- } \\
\text { ered (last } \\
\text { lines of } \\
\text { Column } \\
2 \text { and } \\
\text { Column } \\
3 \text { ) }\end{array}$ & $\begin{array}{l}\text { These } \\
\text { numbers } \\
\text { should } \\
\text { be iden- } \\
\text { tical to } \\
\text { the total } \\
\text { number } \\
\text { of CS } \\
\text { and of } \\
\text { women } \\
\text { deliv- } \\
\text { ered }\end{array}$ & $\mathrm{NA}$ & $\begin{array}{l}\text { Identi- } \\
\text { cal }\end{array}$ & $\begin{array}{l}\text { Data is } \\
\text { correct } \\
\text { and noth- } \\
\text { ing is } \\
\text { missing, } \\
\text { rare possi- } \\
\text { bility of } \\
\text { misclassi- } \\
\text { fication }\end{array}$ \\
\hline $\begin{array}{l}\text { 2. the } \\
\text { size of } \\
\text { Group } 9 \\
\text { (Column } \\
\text { 4) }\end{array}$ & $\begin{array}{l}\text { It should } \\
\text { be less } \\
\text { than } 1 \% \text {. }\end{array}$ & $0.4 \%$ & $0.09 \%$ & $\begin{array}{l}\text { Rate in } \\
\text { line with } \\
\text { both Rob- } \\
\text { son refer- } \\
\text { ences and } \\
\text { MCS ex- } \\
\text { amples. } \\
\text { No mis- } \\
\text { classificati } \\
\text { on }\end{array}$ \\
\hline $\begin{array}{l}3 \text {. the CS } \\
\text { rate of } \\
\text { Group } 9 \\
\text { (Column } \\
5 \text { ) }\end{array}$ & $\begin{array}{l}\text { It should } \\
\text { be } 100 \%\end{array}$ & $88.6 \%$ & $100 \%$ & $\begin{array}{l}\text { Rate in } \\
\text { line with } \\
\text { Robson } \\
\text { references. }\end{array}$ \\
\hline
\end{tabular}


Table-5b: Assessment of type of population using the Robson Classification Report Table obtained from our study

\begin{tabular}{|c|c|c|c|c|}
\hline Steps & $\begin{array}{l}\text { Interpretation by Rob- } \\
\text { son }^{3}\end{array}$ & $\begin{array}{l}\text { Example: } \\
\text { MCS popu- } \\
\text { lation }^{3}\end{array}$ & This study & Further Interpretation $^{3}$ \\
\hline $\begin{array}{l}\text { 1. the size of } \\
\text { Groups } 1+ \\
\text { Group } 2 \text { (Column } \\
\text { 4) }\end{array}$ & $\begin{array}{l}\text { This usually represents } \\
35-42 \% \text { of obstetric } \\
\text { population }\end{array}$ & $38.1 \%$ & $50.43 \%$ & $\begin{array}{l}\text { high proportion of women who have } \\
\text { only one child rather than more than } \\
\text { one child }\end{array}$ \\
\hline $\begin{array}{l}\text { 2. the size of } \\
\text { Groups } 3+4 \\
\text { (Column 4)- }\end{array}$ & $\begin{array}{l}\text { This usually represents } \\
\text { about } 30 \% \text { of women. }\end{array}$ & $46.5 \%$ & $32.93 \%$ & $\begin{array}{l}\text { A bit higher proportion of women } \\
\text { with more than one child rather than } \\
\text { only one child, the size of Groups } 3 \\
+ \text { Group } 4 \text { will be higher than } 30 \%\end{array}$ \\
\hline $\begin{array}{l}\text { 3. the size of } \\
\text { Group } 5 \text { (Column } \\
\text { 4) }\end{array}$ & $\begin{array}{l}\text { It is related to the over- } \\
\text { all CS rate. The size of } \\
\text { Group } 5 \text { is roughly usu- } \\
\text { ally about half of the } \\
\text { total CS rate. }\end{array}$ & $7.2 \%$ & $9.32 \%$ & $\begin{array}{l}\text { Relatively normal or lower rate of } \\
\text { CS in past decades in group } 1 \text { and } 2\end{array}$ \\
\hline $\begin{array}{l}\text { 4. the size of } \\
\text { Groups } 6+7 \\
(\text { Column } 4)\end{array}$ & $3-4 \%$ & $2.7 \%$ & $2.34 \%$ & $\begin{array}{l}\text { Rate in line with Robson MCS ex- } \\
\text { amples. Lower rate of preterm deliv- } \\
\text { eries }\end{array}$ \\
\hline $\begin{array}{l}\text { 5. the size of } \\
\text { Groups } 8 \\
\text { (Column } 4 \text { )- }\end{array}$ & It should be $1.5-2 \%$ & $0.9 \%$ & $0.46 \%$ & $\begin{array}{l}\text { probably a lot of the twins are re- } \\
\text { ferred out }\end{array}$ \\
\hline $\begin{array}{l}\text { 6. The size of } \\
\text { Groups } 10 \\
\text { (Column } 4 \text { ) }\end{array}$ & $\begin{array}{l}\text { It should be less than } \\
5 \% \text { in most normal risk } \\
\text { settings }\end{array}$ & $4.2 \%$ & $3.9 \%$ & $\begin{array}{l}\text { Rate in line with both Robson refer- } \\
\text { ences and MCS examples with high } \\
\text { group CS rate }(41 \%) \text { suggest more } \\
\text { iatrogenic preterm CS conditions }\end{array}$ \\
\hline $\begin{array}{l}\text { 7. The Ratio of } \\
\text { the size of Group } \\
1 \text { versus Group } 2 \\
\text { (Column 4) }\end{array}$ & $\begin{array}{l}\text { It is usually } 2: 1 \text { or high- } \\
\text { er }\end{array}$ & 3.3 & 2.33 & $\begin{array}{l}\text { Rate in line with both Robson refer- } \\
\text { ences and MCS examples suggesting } \\
\text { correct data collection }\end{array}$ \\
\hline $\begin{array}{l}\text { 8. The Ratio of } \\
\text { the size of Group } \\
3 \text { versus Group } 4 \text {. } \\
\text { Column } 4 \text { ) }\end{array}$ & $\begin{array}{l}\text { It is always higher than } \\
\text { the ratio of Group } 1 / \\
\text { Group } 2 \text { in the same } \\
\text { institution, i.e., larger } \\
\text { than } 2: 1\end{array}$ & 6.3 & 3.59 & $\begin{array}{l}\text { Rate in line with both Robson refer- } \\
\text { ences and MCS examples. Confirms } \\
\text { reliable quality of data }\end{array}$ \\
\hline $\begin{array}{l}\text { 9. The Ratio of } \\
\text { the size of Group } \\
6 \text { versus Group } 7 . \\
\text { (Column } 4 \text { ) }\end{array}$ & $\begin{array}{l}\text { It is usually a } 2: 1 \text { be- } \\
\text { cause breeches are more } \\
\text { frequent in nulliparous } \\
\text { women than in multipa- } \\
\text { rous women. }\end{array}$ & 0.8 & 1 & Similar to MCS reference population \\
\hline
\end{tabular}

The manual for interpretation of CS rates stated that the size of group 9 should be less than $1 \%$ of the total and the CS rate should be $100 \%$ for this group. ${ }^{3}$ In this study, the size of group 9 was $0.09 \%$ and the CS rate in this group was $100 \%$, suggesting minimal misclassification in this group, similar results were seen in eight other studies. ${ }^{9,13-17,20,22}$

Several other indicators were in line with the comparison populations given in Robson's manual; the proportion of group 5, size of group 6+7, proportion of Groups 10, the ratio of the size of Group 1 versus Group 2 and the ratio of the size of Group 3 versus Group 4 suggesting correct data collection with confirmation in reliability of data. ${ }^{3}$ Ratio of group 6 to 7 was lesser than given by Robson guideline but was similar to MCS example reference population. ${ }^{3}$ four other studies had similar interpretation. ${ }^{10,14,15,22}$

According to Robson, the proportion of group 5 should be at least half of the entire CS rate. However, in this study the proportion of group 5 represents only $9.32 \%$ which reflects a low CS rate in previous years. Similar results were shown by 3 more studies. ${ }^{8,10,22}$

The CS rate in Robson group 1 was $24.26 \%$, which is much higher than Robson's examples showing that rates under $10 \%$ are achievable. ${ }^{3}$ This reflects a selection among nulliparous, where many normal spontaneous deliveries take place but as this study was conducted in tertiary center with burden of referred in cases 
Table-5c: Assessment of CS rates using Robson report table obtained from our study.

\begin{tabular}{|c|c|c|c|c|}
\hline Steps & Robson guideline $^{3}$ & $\begin{array}{l}\text { MCS } \\
\text { reference } \\
\text { popula- } \\
\text { tion }^{3}\end{array}$ & $\begin{array}{l}\text { This } \\
\text { study }\end{array}$ & Further Interpretation $^{3}$ \\
\hline $\begin{array}{l}\text { 1. CS rate for Group } \\
1(\text { Column } 5)\end{array}$ & $\begin{array}{l}\text { Rates under } 10 \% \text { are } \\
\text { achievable }\end{array}$ & $9.8 \%$ & $24.26 \%$ & $\begin{array}{l}\text { Due to larger group size, rates under } 10 \% \text { is } \\
\text { unachievable }\end{array}$ \\
\hline $\begin{array}{l}\text { 2. CS rate for Group } \\
2(\text { Column } 5)\end{array}$ & $\begin{array}{l}\text { Consistently around } \\
20-35 \%\end{array}$ & $39.9 \%$ & $53.44 \%$ & $\begin{array}{l}\text { High rate of CS in group } 2 \text { with relatively } \\
\text { smaller size of group } 2 \mathrm{~b} \text { indicated poor suc- } \\
\text { cess rates for induction or poor choice of } \\
\text { women to induce and consequently a high } \\
\text { rate of CS in Group } 2 \mathrm{a} \text {. }\end{array}$ \\
\hline $\begin{array}{l}\text { 3. the CS rate for } \\
\text { Group } 3 \text { (Column 5) }\end{array}$ & $\begin{array}{l}\text { Normally, no higher } \\
\text { than } 3.0 \% \text {. }\end{array}$ & $3 \%$ & $10.07 \%$ & $\begin{array}{l}\text { High rate of CS with non-absolute indication } \\
\text { of CS }\end{array}$ \\
\hline $\begin{array}{l}\text { 4. } \mathrm{CS} \text { rate for Group } \\
4(\text { Column } 5)\end{array}$ & $\begin{array}{l}\text { It rarely should be } \\
\text { higher than } 15 \%\end{array}$ & $23.7 \%$ & $30.03 \%$ & $\begin{array}{l}\text { Due to larger size of group } 2 \mathrm{~b} \text {, lesser rate of } \\
\text { induction in multiparous women } \mathrm{h} / \mathrm{o} \text { of previ- } \\
\text { ous complicated vaginal deliveries }\end{array}$ \\
\hline $\begin{array}{l}\text { 5. CS rate for Group } \\
5(\text { Column } 5)\end{array}$ & $\begin{array}{l}\text { Rates of } 50-60 \% \text { are } \\
\text { considered appropri- } \\
\text { ate provided you } \\
\text { have good maternal } \\
\text { and perinatal out- } \\
\text { come. }\end{array}$ & $74.4 \%$ & $99.17 \%$ & $\begin{array}{l}\text { Due to a policy of scheduling pre-labor CS } \\
\text { for all women with } 1 \text { previous scar without } \\
\text { attempting a trial of labor. }\end{array}$ \\
\hline $\begin{array}{l}\text { 6. the CS rate for } \\
\text { Group } 8 \text { (Column } 5)\end{array}$ & $\begin{array}{l}\text { It is usually around } \\
60 \% \text {. }\end{array}$ & $57.5 \%$ & $94.34 \%$ & Variations due to type of twin pregnancy. \\
\hline $\begin{array}{l}\text { 7. CS rate in Group } \\
10(\text { Column } 5)\end{array}$ & $\begin{array}{l}\text { In most populations } \\
\text { it is usually around } \\
30 \%\end{array}$ & $25.1 \%$ & $41.46 \%$ & $\begin{array}{l}\text { It is usually due to many cases of high risk } \\
\text { pregnancies (e.g. fetal growth restriction, } \\
\text { preeclampsia) that will need preterm pre- } \\
\text { labor CS as ours is a referral center }\end{array}$ \\
\hline $\begin{array}{l}\text { 8. Relative contribu- } \\
\text { tion of Groups } 1,2 \\
\text { and } 5 \text { to the overall } \\
\text { CS rate }\end{array}$ & $\begin{array}{l}\text { contribute to } 2 / 3 \\
(66 \%) \text { of all } \mathrm{CS} \text {. }\end{array}$ & $63.7 \%$ & $74.32 \%$ & $\begin{array}{l}\text { These three groups should be the focus of } \\
\text { attention if the hospital is to lower the overall } \\
\text { CS rate.as the overall CS rate is high, the } \\
\text { greater the focus should be in Group } 1 .\end{array}$ \\
\hline $\begin{array}{l}\text { 9. Contribution of } \\
\text { Group } 5 \text { to the over- } \\
\text { all CS rate (Column } \\
\text { 7) }\end{array}$ & & $28.9 \%$ & $26.35 \%$ & $\begin{array}{l}\text { Normal or low rate of CS in group } 1 \text { and } 2 \text { in } \\
\text { past decade }\end{array}$ \\
\hline
\end{tabular}

also it reflects a low 'threshold' interpreting criterion for a CS with high rate of CS for non-absolute indication of CS. Similar results were seen in twelve other studies. ${ }^{9,10,20,22,11-16,18,19}$

The CS rate in group 2 was also higher (55.44\%) than Robson's guideline. ${ }^{3}$ Population in group $2 b$ was relatively smaller indicating poor success rates for induction or poor choice of women to induce and consequently a high rate of CS in Group 2a and hence high rate in group 2. Similar interpretations were made in six more studies. ${ }^{8,9,13,18,20,21}$ This reflects that the threshold for deciding on doing CS is too low, and this could had happened due to extremely busy labor wards where CS maybe preferred over a time-consuming trial of labor.

This 'low' CS threshold may explain why group 3 also had a higher CS rate (10.07\%) than the comparison population $(3 \%-5 \%){ }^{3}$ Similar results were shown by 4 other studies. $13,16,18,20$
Robson guideline stated that the CS rate in group 4 is rarely should be higher than $15 \%$, while in our study this rate was much higher $(30.03 \%))^{3}$ This might be because of the high CS rate group $4 \mathrm{~b}$ (21.68\%), which contributed to the high overall CS rate in group 4. This was due to lower rate of IOL in multiparous patients and high rate of CS in women with history of previous complicated deliveries.

The CS rate in group 5 in this study was $99.17 \%$ which is higher than the Robson guideline $(50 \%-$ $60 \%$ ) as well as WHO MCS reference population ${ }^{3}$ similar results were shown by seven other studies. $^{10-13,15,17,22}$ This might be due to a policy of scheduling pre-labor CS for all women with 1 previous scar without attempting a trial of labor or too few women were offered a trial of labor after having had previous $\mathrm{CS}$. 
According to Robson guidelines rate of CS in group 10 is around $30 \%{ }^{3}$ in this study it was around it was much higher $(41.46 \%)$ this might be explained by the fact that PMWH is a tertiary hospital with high referral case burden of complicated pregnancies with maternal medical indications leading preterm CS. Similar results were seen in four different studies. $^{10,13,17,22}$

The examples given by Robson in his guideline stated that nulliparous and women with a previous CS contribute to $66 \%$ of CS at the hospital, comprising group 1 group 2 and group $5{ }^{3}$ In this study, the relative contribution of these three groups (group 1, 2 and 5) to the overall CS rate was $74.32 \%$.which is slightly higher may because the group size of 1 and 2 are larger. Similar results were shown by eight other studies. . $^{8,911,13,14,17,20,22}$

The overall CS rate in our hospital $(35.08 \%)$ is higher than the WHO recommendation $10 \%-15 \%{ }^{3}$ Similar results were shown by many other studies. ${ }^{7,8,18-22,9,10,12-17}$ The high CS rate in this study had many factors; like PMWH is a tertiary center with high burden of referred and complicated pregnancy cases, high rate of iatrogenic preterm CS, low threshold for CS in low risk group, provision of scheduling CS without trial of labor for patients with previous CS and as this is a teaching hospital under NAMS and has doctors under specialist training performing $\mathrm{CS}$.

Most of patients (56.1\%) belonged to age group of 25 to 34years. Similar results were shown by six different studies. ${ }^{8,9,13,18,19,22}$ Major proportion of patients enrolled in study were primigravida (43.66\%). More than half were nulliparous (51.46\%) and more than one third had parity 1 (39.03\%). Except for few patients all most all of sample population $(99.02 \%)$ had singleton pregnancy, more than $90 \%$ had longitudinal lie with cephalic presentation. More than $3 / 4^{\text {th }}$ of the sample populations were admitted at term pregnancy (37 to 42 weeks). Majority of patients had spontaneous onset of labor at admission $(46.83 \%)$ more than one third were not in labor $(38.29 \%)$ whereas only $14.88 \%$ underwent IOL suggesting high rate of pre-labor indications of CS and low threshold for CS at our study site. Around one third of patients had history of previous CS $(31.22 \%)$.

On classifying sample population according to RTGCS it was found that group 1,2 and 5 in combination contributed $70.73 \%$ to overall CS rate similar to the total population during study. Hence the sample population (patients enrolled in the study) represented the total population.

On study of indication for admission sample population, it was found that $25.36 \%$ patients were admitted for previous CS status, $18.29 \%$ patients were in LPOL and $11.70 \%$ patients were postdated pregnancies admitted for induction of labor. But majority of patient underwent CS for indication of previous CS status $(25.85 \%)$ and fetal distress as indication of CS (25.54\%). Similar indications have been reported in multiple other studies. ${ }^{11-}$ $13,16,17,19,23,24$

Among patients underwent CS for fetal distress $65.43 \%$ belonged to group 1 and 2 (low risk group). Statistically significantly relation was found between fetal distress as indication for CS among low risk group also these groups had statistically significant rise of fetal distress after admission. High contribution to CS rate it is due to large group size as group CS rate is comparatively lower when compare to other groups and more than $3 / 4^{\text {th }}$ of patients form these groups delivered vaginally .

This high proportion and rise of fetal distress as indication for CS might be due to non-optimal fetal monitoring, misdiagnosis of abnormal fetal heartbeat pattern, lack of watchful management of progression of labor and low threshold for CS. In this scenario misleading criteria of group 1 and 2 from RTGCS might lower the threshold of CS even more and increase rate of CS due to higher anticipation of CS in low risk group.

Highest rate of maternal complication was seen in group $2(67.74 \%)$, more than half of overall maternal complications were contributed by group 1and 2 (15.9\% and $35.44 \%$ respectively). These high rates of complication in low risk group also suggest towards need to decrease CS rate in these groups.

\section{CONCLUSIONS}

Low risk group had higher contribution to overall CS rate. Major indication for CS was fetal distress and significant rise of fetal distress after admission was seen in these group but this indication isn't mentioned in criteria of RTGCS, hence RTGCS couldn't predict indication of CS properly for these low risk group and falsely drew attention towards these group with higher than required anticipation of CS. Also vague criteria of group 1 and 2 without any mentioning of high risk indication like fetal distress shows the limitation of RTGCS in predicting CS in low risk group. 
According to Robson guidelines rate of CS in group 10 is around $30 \%{ }^{3}$ in this study it was around it was much higher $(41.46 \%)$ this might be explained by the fact that PMWH is a tertiary hospital with high referral case burden of complicated pregnancies with maternal medical indications leading preterm CS. Similar results were seen in four different studies. $^{10,13,17,22}$

The examples given by Robson in his guideline stated that nulliparous and women with a previous CS contribute to $66 \%$ of CS at the hospital, comprising group 1 group 2 and group $5{ }^{3}$ In this study, the relative contribution of these three groups (group 1, 2 and 5) to the overall CS rate was $74.32 \%$.which is slightly higher may because the group size of 1 and 2 are larger. Similar results were shown by eight other studies. ${ }^{8,9,11,13,14,17,20,22}$

The overall CS rate in our hospital $(35.08 \%)$ is higher than the WHO recommendation $10 \%-15 \%{ }^{3}$ Similar results were shown by many other studies. ${ }^{7,8,18-22,9,10,12-17}$ The high CS rate in this study had many factors; like PMWH is a tertiary center with high burden of referred and complicated pregnancy cases, high rate of iatrogenic preterm CS, low threshold for CS in low risk group, provision of scheduling CS without trial of labor for patients with previous CS and as this is a teaching hospital under NAMS and has doctors under specialist training performing $\mathrm{CS}$.

Most of patients (56.1\%) belonged to age group of 25 to 34years. Similar results were shown by six different studies. ${ }^{8,9,13,18,19,22}$ Major proportion of patients enrolled in study were primigravida (43.66\%). More than half were nulliparous (51.46\%) and more than one third had parity 1 (39.03\%). Except for few patients all most all of sample population $(99.02 \%)$ had singleton pregnancy, more than $90 \%$ had longitudinal lie with cephalic presentation. More than $3 / 4^{\text {th }}$ of the sample populations were admitted at term pregnancy ( 37 to 42 weeks). Majority of patients had spontaneous onset of labor at admission $(46.83 \%)$ more than one third were not in labor $(38.29 \%)$ whereas only $14.88 \%$ underwent IOL suggesting high rate of pre-labor indications of CS and low threshold for CS at our study site. Around one third of patients had history of previous CS $(31.22 \%)$.

On classifying sample population according to RTGCS it was found that group 1,2 and 5 in combination contributed $70.73 \%$ to overall CS rate similar to the total population during study. Hence the sample population (patients enrolled in the study) represented the total population.

On study of indication for admission sample population, it was found that $25.36 \%$ patients were admitted for previous CS status, $18.29 \%$ patients were in LPOL and $11.70 \%$ patients were postdated pregnancies admitted for induction of labor. But majority of patient underwent CS for indication of previous CS status $(25.85 \%)$ and fetal distress as indication of CS (25.54\%). Similar indications have been reported in multiple other studies. ${ }^{11-}$ $13,16,17,19,23,24$

Among patients underwent CS for fetal distress $65.43 \%$ belonged to group 1 and 2 (low risk group). Statistically significantly relation was found between fetal distress as indication for CS among low risk group also these groups had statistically significant rise of fetal distress after admission. High contribution to CS rate it is due to large group size as group CS rate is comparatively lower when compare to other groups and more than $3 / 4^{\text {th }}$ of patients form these groups delivered vaginally .

This high proportion and rise of fetal distress as indication for CS might be due to non-optimal fetal monitoring, misdiagnosis of abnormal fetal heartbeat pattern, lack of watchful management of progression of labor and low threshold for CS. In this scenario misleading criteria of group 1 and 2 from RTGCS might lower the threshold of CS even more and increase rate of CS due to higher anticipation of CS in low risk group.

Highest rate of maternal complication was seen in group $2(67.74 \%)$, more than half of overall maternal complications were contributed by group 1and 2 (15.9\% and $35.44 \%$ respectively). These high rates of complication in low risk group also suggest towards need to decrease CS rate in these groups.

\section{CONCLUSIONS}

Low risk group had higher contribution to overall CS rate. Major indication for CS was fetal distress and significant rise of fetal distress after admission was seen in these group but this indication isn't mentioned in criteria of RTGCS, hence RTGCS couldn't predict indication of CS properly for these low risk group and falsely drew attention towards these group with higher than required anticipation of CS. Also vague criteria of group 1 and 2 without any mentioning of high risk indication like fetal distress shows the limitation of RTGCS in predicting CS in low risk group. 
The group CS rates were higher for low risk group in comparison to MCS reference population and Robson guidelines significantly due to fetal distress; indicated towards high proportion of misdiagnosis of fetal distress and low threshold for CS in these group. Hence improving fetal heartbeat-monitoring system, proper CTG interpretation focused on appropriate diagnosis of non-reassuring pattern to decrease the misdiagnosis of fetal distress and incorporation of "fetal distress" or condition which gives rise to fetal distress into RTGCS are recommended to decrease the burden of $\mathrm{CS}$ in these low risk groups.

\section{REFERENCES}

1. Villar J, Valladares E, Wojdyla D, Zavaleta N, Carroli G, Velazco A, et al. Caesarean delivery rates and pregnancy outcomes: the 2005 WHO global survey on maternal and perinatal health in Latin America. Lancet (London, England). 2006;367(9525):1819-29. [Link]

2. Gibbons L, Belizán JM, Lauer JA, Betrán AP, Merialdi M, Althabe F. The Global Numbers and Costs of Additionally Needed and Unnecessary Caesarean Sections Performed per Year: Overuse as a Barrier to Universal Coverage World Health Report (2010) Background Paper, 30 Health System Financing.

3. WHO. Robson Classification Implementation Manual [Internet]. [cited 2021 Apr 26]. Available from: http://apps.who.int/iris/bitstream/ handle/10665/259512/9789241513197eng.pdf;jsessionid=BAB9E4DBBFBAC88269D A3548865A101D?sequence $=1$

4. Dixon N, Pearce M. Clinical audit tool to promote quality for better health services Guide to Ensuring Data Quality in Clinical Audits. 2011.

5. Press RM. Principles for Best Practice in Clinical Audit [Internet]. [cited 2021 Apr 26]. Available from: www.radcliffe-oxford.com

6. Cunningham FG, Lenovo KJ, Bloom SL, Dashe JS, Hoffman BL, Casey BM, Spong CY editors. Williams Obstetrics. 2018.

7. Say L, Souza JP, Pattinson RC. Maternal near miss--towards a standard tool for monitoring quality of maternal health care. Best Pract Res Clin Obstet Gynaecol. 2009;23(3):287-96.

8. Cammu H, Martens E, Van Maele G. Using the Robson Classification to Explain the Fluctuations in Cesarean Section. Marozio L, editor. J Pregnancy [Internet]. 2020;2020:2793296.
Available
from:
doi.org/10.1155/2020/2793296

https://

9. Abubeker FA, Gashawbeza B, Gebre TM, Wondafrash M, Teklu AM, Degu D, et al. Analysis of cesarean section rates using Robson ten group classification system in a tertiary teaching hospital, Addis Ababa, Ethiopia: a cross-sectional study. BMC Pregnancy Childbirth [Internet]. 2020;20(1):767. Available from: https://doi.org/10.1186/s12884-02003474-x

10. Senanayake H, Piccoli M, Valente EP, Businelli C, Mohamed R, Fernando R, et al. Implementation of the WHO manual for Robson classification: an example from Sri Lanka using a local database for developing quality improvement recommendations. BMJ Open [Internet]. 2019;9(2):e027317. Available from: http://bmjopen.bmj.com/content/9/2/ e027317.abstract

11.Robson M, Murphy M, Byrne F. Quality assurance: The 10-Group Classification System (Robson classification), induction of labor, and cesarean delivery. Int J Gynaecol Obstet Off organ Int Fed Gynaecol Obstet. 2015;131 Suppl:S23-7.

12.Makhanya V, Govender L, Moodley J. Utility of the Robson Ten Group Classification System to determine appropriateness of caesarean section at a rural regional hospital in KwaZuluNatal, South Africa. S Afr Med J. 2015;105 (4):292-5.

13. Abdo AA, Hinderaker SG, Tekle AG, Lindtjørn B. Caesarean section rates analysed using Robson's 10-Group Classification System: a crosssectional study at a tertiary hospital in Ethiopia. BMJ Open [Internet]. 2020;10(10):e039098. Available from: http://bmjopen.bmj.com/ content/10/10/e039098.abstract

14. Karalasingam SD, Jeganathan R, Jegasothy R, Reidpath DD. Caesarean section rates from Malaysian tertiary hospitals using Robson's 10group classification. BMC Pregnancy Childbirth [Internet]. 2020;20(1):64. Available from: https://doi.org/10.1186/s12884-020-2760-2

15. Jogia PD, Lodhiya KK. Analysis of caesarean sections according to modified Robson's ten group classification system at a tertiary care centre in Western India. Int J Reprod Contracep Obstet Gynecol. 2019;8(2). DOI: 1018203/2320-1770.ijrcog20190264

[Internet]. URL: https://www.ijrcog.org/ index.php/ijrcog/article/view/5919

16. Tura AK, Pijpers O, de Man M, Cleveringa M, Koopmans I, Gure T, et al. Analysis of caesarean sections using Robson 10-group classification system in a university hospital in eastern Ethiopia: a cross-sectional study. BMJ Open. 
2018;8(4):e020520.

17. Robson MS. The 10-Group Classification System-a new way of thinking. Am J Obstet Gynecol [Internet]. 2018;219(1):1-4. URL: http:// europepmc.org/abstract/MED/29941276

18. Triunfo S, Ferrazzani S, Lanzone A, Scambia G. Identification of obstetric targets for reducing cesarean section rate using the Robson Ten Group Classification in a tertiary level hospital. Eur J Obstet Gynecol Reprod Biol. 2015;189:91-5.

19. Tanaka K, Mahomed K. The Ten-Group Robson Classification: A Single Centre Approach Identifying Strategies to Optimise Caesarean Section Rates. Coleman R, editor. Obstet Gynecol Int [Internet]. 2017;2017:5648938. URL: https://doi.org/10.1155/2017/5648938

20. Alsulami SM, Ashmawi MT, Jarwan RO, Malli IA, Albar SK, Al-Jifree HM. The Rates of Cesarean Section Deliveries According to Robson Classification System During the Year of 2018 Among Patients in King Abdul-Aziz Medical City, Jeddah, Saudi Arabia. Cureus. 2020;12 (11):e11529.

21. Samba A, Mumuni K. A review of caesarean sections using the ten-group classification system (Robson classification) in the Korle-Bu Teaching Hospital (KBTH), Accra, Ghana. Gynecol Obs. 2016;6(385):932-2161.
22. Dhodapkar SB, Bhairavi S, Daniel M, Chauhan NS, Chauhan RC. Analysis of caesarean sections according to Robson's ten group classification system at a tertiary care teaching hospital in South India. Int J Reprod Contracep Obstet Gynecol. 2015;4(3). DOI: 1018203/2320-1770.ijrcog20150085

[Internet]. 2017 Feb 8; URL: https:// www.ijrcog.org/index.php/ijrcog/article/ view/1995

23. Tognon F, Borghero A, Putoto G, Maziku D, Torelli GF, Azzimonti G, et al. Analysis of caesarean section and neonatal outcome using the Robson classification in a rural district hospital in Tanzania: an observational retrospective study. BMJ Open [Internet]. 2019;9 (12):e033348. URL: http://bmjopen.bmj.com/ content/9/12/e033348.abstract

24. Begum T, Nababan H, Rahman A, Islam MR, Adams A, Anwar I. Monitoring caesarean births using the Robson ten group classification system: A cross-sectional survey of private for-profit facilities in urban Bangladesh. PLoS One. 2019;14(8):e0220693. 